\title{
Jesus se Woorde vir Mans
}

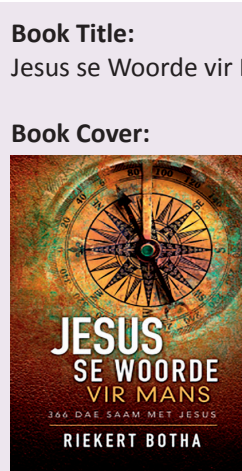

Author:

Riekert Botha

ISBN:

978-1-4316-1083-9

\section{Publisher:}

Vereeniging: Christelike

Uitgewersmaatskappy, 2015,

R139.95*

*Book price at time of review

Review Title:

Dagstukkies vir mans

\section{Reviewer:}

P.H. Heystek ${ }^{1}$

\section{Affiliation:}

${ }^{1}$ Reformed Church Pretoria-

Montanapoort, South Africa

Email:

drpieter@montanapoort.co.za

Postal address:

PO Box 1697, Montanapark

0159, South Africa

\section{How to cite this book review:}

Heystek, P.H., 2015,

'Dagstukkies vir mans',

In die Skriflig 49(1), Art.

\#2009, 1 page. http://dx.doi

org/10.4102/ids.v49i1.2009

\section{Copyright:}

(C) 2015. The Authors.

Licensee: AOSIS

OpenJournals. This work is

licensed under the Creative

Commons Attribution

License.

\section{Read online:}

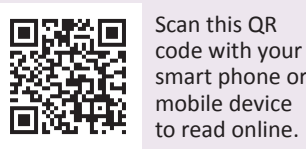

Botha se boek Jesus se woorde vir mans bestaan uit kort dagstukkies van nie meer as 120 woorde nie. Daar is 'n verklaring van 'n spesifieke teksvers uit die Bybel vir elke dag van die jaar.

Wat opvallend is, is dat geen vers-eenheid aangedui word nie; slegs 'n teksvers. Die leser word dus nie gelei om die Bybel planmatig en doelmatig te lees nie. In die aanbieding van die dagstukkies word teksverse 'na willekeur' gebruik: elke dag 'n ander teks. Dit is dus nie noodwendig stimulerend vir sistematiese Bybellees nie. Geen openbarings-historiese lyn word voorop gestel nie.

Elke dagstukkie getuig van goeie eksegese en die toepassing van die teksboodskap is duidelik en maklik verstaanbaar. Dit bied verder ' $n$ bybelse kernwaarheid wat die leser se lewe positief kan beïnvloed. Die titel Jesus se woorde vir mans is beperkend omdat Botha self in die voorwoord skryf dat die dinge wat Jesus sê 'is nie bloot opinies nie, maar werklik lewegewende waarhede wat mense se lewens radikaal kan verander as hulle daaraan gehoor gee'. Die dagstukkies waarin tekste kortliks verklaar word, is dus nie eksklusief 'woorde vir mans' nie. Inteendeel, dit is Jesus se woorde en dus geldig vir albei geslagte.

Jesus se woorde vir mans is 'n populêr-wetenskaplike bundel met bybelse dagstukkies en sal by baie Christene aanklank vind. Mans sowel as vroue wat daarvan hou om gereeld dagstukkies te lees, sal die boek 'n welkome toevoeging vind tot die vele publikasies van hierdie aard wat al in die verlede verskyn het.

Die publikasie is keurig versorg en 'n ideale geskenk vir verkieslik mans om Jesus se woorde te hoor en dit geïnspireerd dag vir dag uit te leef. 